\title{
Scaling of ammonium uptake by seaweeds to surface area:volume ratio: geographical variation and the role of uptake by passive diffusion
}

\author{
Richard B. Taylor, Jeroen T. A. Peek, T. Alwyn V. Rees* \\ Leigh Marine Laboratory, University of Auckland, PO Box 349, Warkworth, New Zealand
}

\begin{abstract}
Rates of ammonium uptake per g dry weight for seaweeds from the Mokohinau Islands, northeastern New Zealand were much lower than published values for northern hemisphere (east coast of North America and Baltic Sea) seaweeds. For the New Zealand seaweeds, the rate of ammonium uptake expressed per $\mathrm{cm}^{2}$ surface area was relatively constant $\left(23.9 \pm 3.4 \mathrm{nmol} \mathrm{cm}^{-2} \mathrm{~h}^{-1}\right)$, irrespective of seaweed surface area:volume (SA:V) ratio. Moreover, there was a linear relationship between rates of ammonium uptake per $g$ dry weight and ammonium concentration for 2 of the species used, Xiphophora chondrophylla and Ulva sp., which had low and high SA:V ratios, respectively. These results are consistent with most or all of ammonium uptake being due to passive diffusion of $\mathrm{NH}_{3}$. In addition, of 3 other species investigated, Pterocladia capillacea, Porphyra sp. and Enteromorpha sp., only $P$. capillacea exhibited saturation kinetics.
\end{abstract}

KEY WORDS: Seaweed N Nutrient uptake Ammonium Diffusion New Zealand

\section{INTRODUCTION}

Seaweed-based ecosystems are amongst the most productive on Earth (Mann et al. 1980, Leigh et al. 1987). This high productivity is particularly surprising given that some of the major nutrients (e.g, nitrogen and phosphorus) required for growth are often present at low concentrations in coastal waters (Sharp 1983. Lobban \& Harrison 1994). Seaweeds acquire these nutrients through uptake across the entire surface area of the thallus. Consequently, the rate of uptake of a given nutrient should be a function of the surface area presented by the seaweed per unit of its biomass, in other words, its surface area:volume (SA:V) ratio. In general, this relationship has been observed (Rosenberg \& Ramus 1984, Hein et al. 1995), with rates of uptake per unit biomass being positively correlated with SA:V ratio. However, most of this data has been compiled for the east coast of North America and the

\footnotetext{
-Addressee for correspondence.
}

E-mail: ta.rees@auckland.ac.nz
Baltic Sea, giving little impression of any geographical variation. Furthermore, the mechanistic basis (e.g. whether uptake is active and/or passive) of this compelling relationship has not been explored in any detail.

Ammonium can be taken up by an alga in 2 forms, i.e. active uptake of $\mathrm{NH}_{4}{ }^{+}$and/or passive diffusion of $\mathrm{NH}_{3}$ (Raven 1984, Rees 1995). For seaweeds, the dominant line of evidence for the former is saturable uptake kinetics, though a combination of saturable and linear kinetics indicates the involvement of both mechanisms (Harrison \& Druehl 1982). A major reason for the apparent importance of an active uptake mechanism is the typically low concentration of ammonium in seawater (Sharp 1983). However, it should be noted that uptake of ammonium measures an ill-defined combination of active and/or passive transport at the plasma membrane and assimilation within the cell or tissue (Rees et al. 1998).

In this paper, we compare the relationship between the rate of ammonium uptake per unit biomass and $S A: V$ ratio of seaweeds from northeastern New Zealand with that for seaweeds from the northern 
hemisphere (east coast of North America and the Baltic Sea). We then investigate the hypothesis that low observed rates of ammonium uptake in New Zealand seaweeds are due to the absence of an active uptake system for ammonium in these plants.

\section{METHODS}

Glossophora kunthii (C. Agardh) J. Agardh, Zonaria turneriana J Agardh (Phaeophyceae, Dictyotales), Xiphophora chondrophylla (Turner) Montagne ex Harvey (Phaeophyceae, Fucales), Lessonia variegata J. Agardh (Phaeophyceae, Laminariales), and Ulva sp. (Chlorophyceae, Ulvales) were collected from 1 to $5 \mathrm{~m}$ depth at the Mokohinau Islands, in temperate northeastern New Zealand $\left(35^{\circ} 55^{\prime} \mathrm{S}, 175^{\circ} 7^{\prime} \mathrm{E}\right)$ on 9 occasions (4 to 11 wk apart) between November 1994 and December 1995 . The annual range of surface seawater temperature is 14 to $21^{\circ} \mathrm{C}$. Plants were transported to the laboratory submerged in a shaded fish bin and rates of ammonium uptake were determined within 6 to $8 \mathrm{~h}$ of collcction. Water samples for nutrient analysis were taken from just below the surface adjacent to the seaweed collection site and transported on ice to the laboratory, where they were filtered (GF/F) and analysed immediately (ammonium) or after freezing (nitrate and nitrite). Nutrient concentrations were determined by established procedures for ammonium (Koroleff 1983) and nitrate and nitrite (Parsons et al. 1984). Total inorganic nitrogen (ammonium, nitrate and nitrite) ranged from $0.45 \mu \mathrm{M}$ (January 1995) to $4.73 \mu \mathrm{M}$ (November 1994). Ammonium ranged from $0.03 \mu \mathrm{M}$ (December 1994) to $1.93 \mu \mathrm{M}$ (November 1994).

Entire individual plants were incubated in perspex chambers containing 0.2 to $2 \mathrm{l}$ seawater at $17.5^{\circ} \mathrm{C}$ and $40 \mu \mathrm{mol}$ photons $\mathrm{m}^{-2} \mathrm{~s}^{-1}$ (photosynthetically active radiation), with approximately 10 (Glossophora kunthii), 60 (Lessonia variegata), 15 (Ulva sp.), 50 (Xiphophora chondrophylla) or 12 (Zonaria turneriana) g wet weight plant per litre seawater. The photon flux density used was sufficient to give maximum rates of ammonium uptake in the presence of $10 \mu \mathrm{M}$ ammonium (R. B. Taylor \& T. A. V Rees unpubl.). With the exception of experiments determining the effect of ammonium concentration on the rate of uptake, all rates were determined in the presence of $10 \mu \mathrm{M}$ ammonium chloride (2 replicates per seaweed species for each determination). Water samples were taken following stirring by hand and immediately prior to addition of the plant, and at 2.5, 5, 7.5, 10, 15 and $20 \mathrm{~min}$. Water was not stirred mechanically; aeration or continuous stirring had a negligible effect on rates of ammonium uptake (R. B. Taylor \& T. A. V. Rees unpubl.). Dry weights (DW) of plant tissue used in the experiments were determined by drying at $80^{\circ} \mathrm{C}$ to constant weight. The rate of ammonium uptake for each replicate plant was calculated by taking the slope at time zero of an exponential rise curve fitted to a plot of cumulative ammonium in the plant (= disappearance from medium) versus time, as described by Taylor \& Rees (in press). Seaweed surface area was determined from the weight of photocopies of subsamples; seaweed volume was determined by displacement in water, using a graduated cylinder.

We chose to measure rates of uptake in the presence of $10 \mu \mathrm{M}$ ammonium because this was the concentration used by Rosenberg \& Ramus (1984), thereby allowing direct comparison with their data. For other data from the literature, uptake rates at $10 \mu \mathrm{M}$ were calculated from published values for $K_{\mathrm{m}}$ and $V_{\max }$ (compiled by Hein et al. 1995), using the MichaelisMenten equation, with $K_{\mathrm{m}}$ expressed as $\mu \mathrm{M}$ and $V_{\max }$ as $\mu$ mol $\mathrm{g} \mathrm{DW}^{-1} \mathrm{~h}^{-1}$. For the data from the Baltic Sea (Wallentinus 1984 ) only rates determined at $10^{\circ} \mathrm{C}$ or higher were used. Only data for seaweeds with a SA:V ratio less than $250 \mathrm{~cm}^{2}: 1 \mathrm{~cm}^{3}$ were used.

Rates of ammonium uptake were measured at ammonium concentrations ranging from 5 to $100 \mu \mathrm{M}$ for Ulva sp. from the Mokohinau Islands (July 1995), and for Xiphophora chondrophylla (September 1995), Pterocladia capillacea (Gmelin) Bornet et Thuret (Rhodophyceae, Gelidiales) (September 1995), Porphyra sp. (Rhodophyceae, Bangiales) (July 1995) and Enteromorpha sp. (Chlorophyceae, Ulvales) (September 1995) from Goat Island, mainland northeastern New Zealand $\left(36^{\circ} 16^{\prime} \mathrm{S}, 174^{\circ} 48^{\prime} \mathrm{E}\right)$, as described above, with 3 replicates per ammonium concentration.

Reduced major axis (RMA) regression (Sokal \& Rohlf 1995) was used to describe relationships between SA:V ratio and uptake rate. Analysis of covariance was used to test for differences in uptake rates among regions (with SA:V ratio as the covariate). Where relationships between uptake rate and ammonium concentration were linear they were described using ordinary least squares regression, with the line constrained to pass through the origin. A Michaelis-Menten curve was fitted to non-linear relationships between uptake rate and ammonium concentration, using an iterative least squares method (SigmaPlot ${ }^{\circledR}$ ).

\section{RESULTS}

There was a strong positive correlation between log $\mathrm{SA}: \mathrm{V}$ ratio and $\log$ rate of ammonium uptake per $g$ DW for the 5 New Zealand seaweeds (Fig. 1). Data from the 9 sampling periods were pooled as there were no significant differences $(\alpha=0.05)$ in slopes or elevations amongst regression lines for the individual sampling 


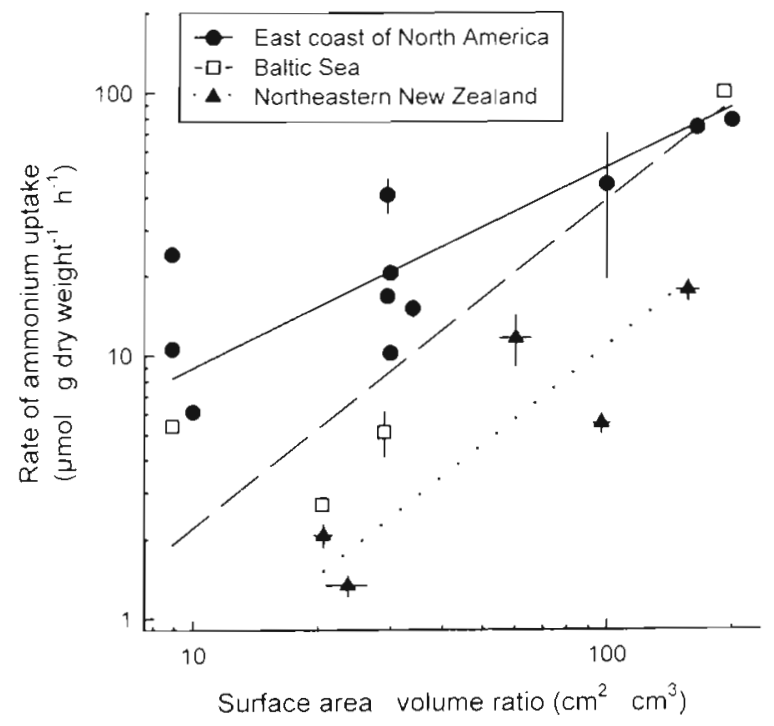

Fig. 1. Biomass-specific rate of ammonium uptake versus SA:V ratio for seaweeds from northeastern New Zealand, the east coast of North America and the Baltic Sea. Each data point corresponds to a single species. Error bars represent 1 SE. Reduced major axis regression equations and coefficients of determination are as follows. North America: $y=$ $1.542 x^{0.765}, \mathrm{r}^{2}=0.66, \mathrm{p}<0.01$; Baltic Sea: $y=0.124 x^{1250}, \mathrm{r}^{2}=$ $0.78, p>0.1$; New Zealand: $y=0.034 x^{1253}, r^{2}=0.79, p<0.05$

periods (tests run on log-log data following Zar 1984), and plots of ammonium uptake rate versus time for each seaweed species showed no apparent seasonal trends (data not shown).

Seaweeds from the Baltic Sea and the east coast of North America also exhibited strong positive correlations between log rate of ammonium uptake per g DW and $\log \mathrm{SA}: \mathrm{V}$ ratio (Fig. 1). However, there were substantial differences in uptake rates among the 3 regions (Fig. 1; ANCOVA: $F=15.53, p<0.001$ ). Rates were highest in North America, intermediate in the Baltic, and lowest in New Zealand. Uptake rates of the New Zealand and North American seaweeds were significantly different (ANCOVA: $p=0.0001$ ), but rates of the Baltic seaweeds did not differ significantly from the New Zealand or the North American seaweeds $(p>0.05)$. Uptake rates of North American seaweeds were 10.5 times higher than those for New Zealand plants at a SA:V ratio of $20 \mathrm{~cm}^{2}: 1 \mathrm{~cm}^{3}$, and 3.4 times higher at a $\mathrm{SA}: \mathrm{V}$ ratio of $200 \mathrm{~cm}^{2}: 1 \mathrm{~cm}^{3}$. Uptake rates of Baltic seaweeds were 3.6 times higher than the New Zealand plants across all $\mathrm{SA}: \mathrm{V}$ ratios.

Rates of ammonium uptake per $\mathrm{cm}^{2}$ of seaweed surface showed no clear relationship to $\mathrm{SA}: \mathrm{V}$ ratio for the 5

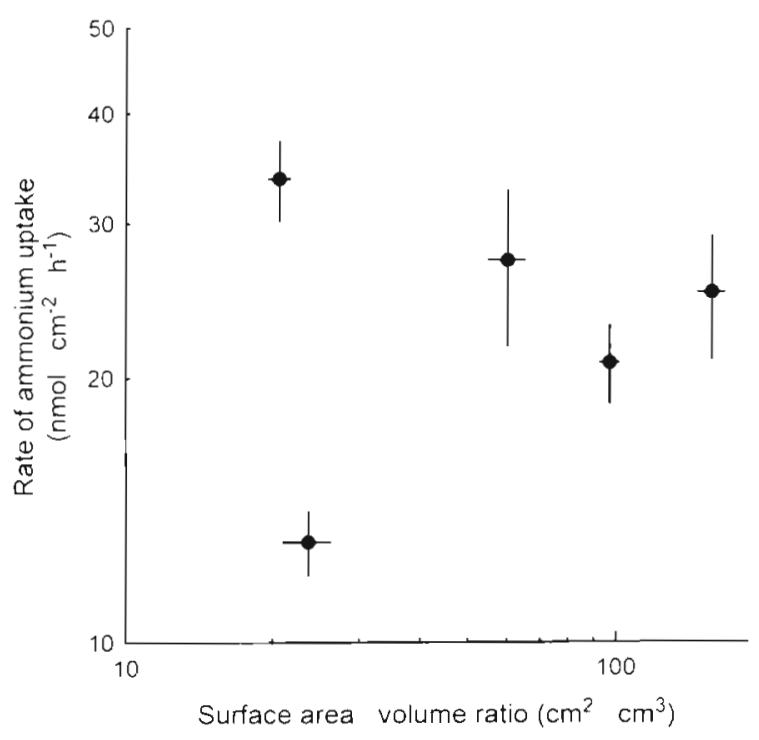

Fig. 2. Area-specific rate of ammonium uptake versus SA:V ratio for seaweeds from the Mokohinau Islands, northeastern New Zealand. Error bars represent $1 \mathrm{SE}$

New Zealand seaweed species $\left(r^{2}=0.015, p=0.85\right)$ (Fig. 2). The range of variation in uptake rates per unit surface area (2.6-fold) was far lower than for the massspecific uptake rates (13.6-fold) (Table 1). The mean rate of uptake for the 5 species was $23.9(\mathrm{SE}=3.4) \mathrm{nmol}$ $\mathrm{cm}^{-2} \mathrm{~h}^{-1}$. One interpretation of this constancy, and the low rates of ammonium uptake (Fig. 1, Table 1), is that uptake of ammonium was due predominantly to passive diffusion of the uncharged base, $\mathrm{NH}_{3}$. If so, for these seaweeds, the rate of ammonium uptake should be a linear function of ammonium concentration. For both Xiphophora chondrophylla (Fig. 3A) and Ulva sp. (Fig. 3B), which were the seaweeds with the lowest and highest SA:V ratios respectively (Table 1 ), rates of ammonium uptake were a linear function of ammonium concentration. Of the other species, Porphyra sp. (Fig. 3C), Enteromorpha sp. (Fig. 3D), and Pterocladia capillacea (Fig. 3E), only P. capillacea exhibited saturation kinetics.

Table 1. Surface area:volume ratios and rates of ammonium uptake at $10 \mu \mathrm{M}$ for 5 seaweed species from northeastern New Zealand. Values are mean $\pm 1 \mathrm{SE}$. $\mathrm{n}$ : total number of plants sampled, usually 2 individuals per sampling period

\begin{tabular}{|lrrrr|}
\hline Species & $\mathrm{n}$ & $\begin{array}{l}\mathrm{SA} V \mathrm{~V} \text { ratio } \\
\left(\mathrm{cm}^{2} \mathrm{~cm}^{3}\right)\end{array}$ & $\begin{array}{c}\text { Uptake rate } \\
\left(\mu \mathrm{mol} \mathrm{g} \mathrm{DW} \mathrm{h}^{-1}\right)\end{array}$ & $\begin{array}{c}\text { Uptake rate } \\
\left(\mathrm{nmol} \mathrm{cm}^{-2} \mathrm{~h}^{-1}\right)\end{array}$ \\
\hline Glossophora kunthii & 7 & $60.3 \pm 5.3$ & $11.6 \pm 2.6$ & $27.2 \pm 5.5$ \\
Lessonia variegata & 18 & $23.7 \pm 2.6$ & $1.3 \pm 0.1$ & $13.0 \pm 1.1$ \\
Ulva sp. & 18 & $156.8 \pm 9.9$ & $17.7 \pm 1.6$ & $25.0 \pm 4.0$ \\
Xiphophora chondrophylla & 18 & $20.7 \pm 1.0$ & $2.1 \pm 0.2$ & $33.7 \pm 3.5$ \\
Zonaria turneriana & 16 & $97.3 \pm 4.4$ & $5.5 \pm 0.5$ & $20.8 \pm 2.1$ \\
& & & & \\
\hline
\end{tabular}




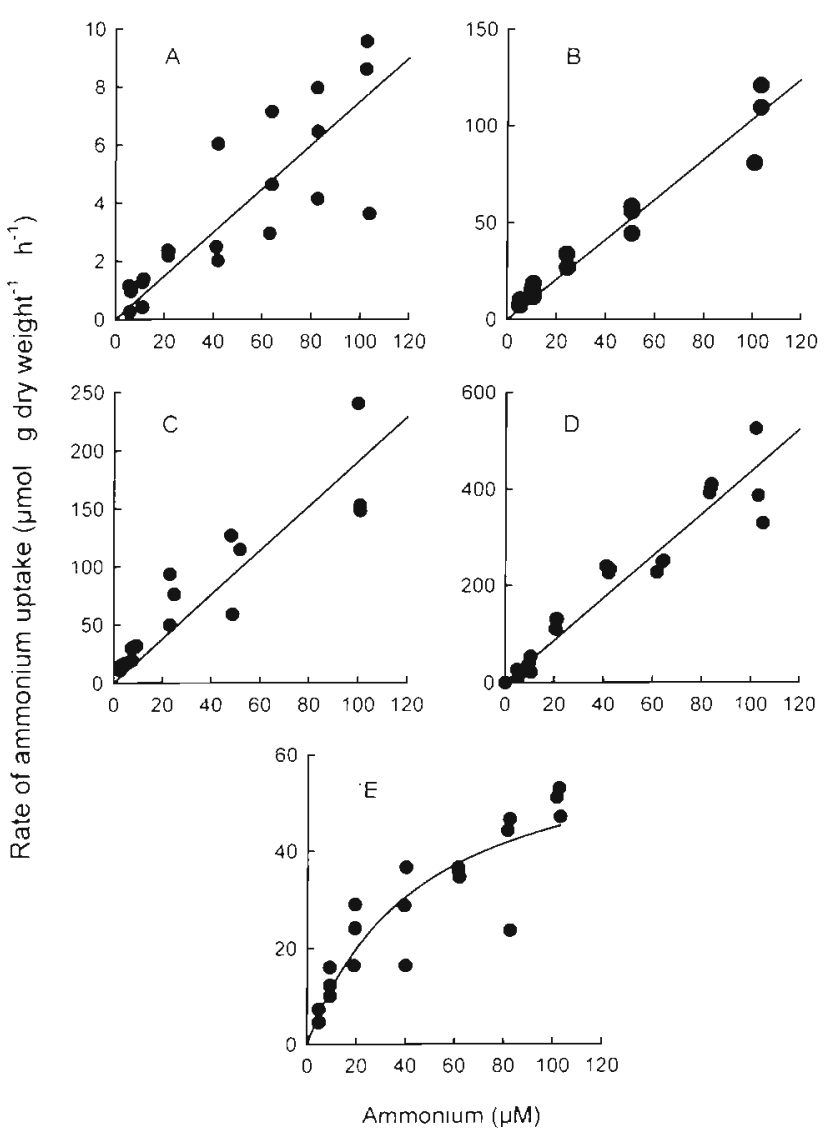

Fig. 3. Effect of ammonium concentration on rate of ammonium uptake by the northeastern New Zealand seaweeds (A) Xiphophora chondrophylla, (B) Ulva sp., (C) Porphyra sp., (D) Enteromorpha sp. and (E) Pterocladia capillacea. For (A) to (D), the regression line is constrained to pass through the origin. A Michaelis-Menten curve is fitted for (E), with $K_{\mathrm{m}}=$ $45 \mu \mathrm{M}$ and $V_{\max }=65 \mu \mathrm{mol} \mathrm{g} \mathrm{DW} W^{-1} \mathrm{~h}^{-1}$

\section{DISCUSSION}

The low rates of ammonium uptake per $g$ dry weight compared with seaweeds from the northern hemisphere (Fig. 1j, the relatively constant rate of uptake per $\mathrm{cm}^{2}$ of seaweed surface (Fig. 2), and the linear relationship between rate of ammonium uptake and ammonium concentration for 5 out of 6 seaweeds from northeastern New Zealand (Fig. 3) (Taylor \& Rees in press) suggest that uptake was due largely to passive diffusion of $\mathrm{NH}_{3}$. From the rate of uptake per unit surface area (6.64 $\left.\times 10^{-8} \mathrm{~mol} \mathrm{~m}^{-2} \mathrm{~s}^{-1}\right)$ (Fig. 2), we calculate (as described in Ritchie \& Gibson 1987) an apparent permeability for $\mathrm{NH}_{3}$ of $155 \mu \mathrm{m} \mathrm{s}^{-1}$ (assuming $\mathrm{pH}=8.3$; $\mathrm{p} K=9.65$ ). This value is high compared with values for freshwater algae and cyanobacteria of about $6 \mu \mathrm{m} . \mathrm{s}^{-1}$ (Barr et al. 1974, Ritchie 1987, Ritchie \& Gibson 1987). However, values for animal membranes range from 5 to $2100 \mathrm{\mu m} \mathrm{s}^{-1}$ (Labotka et al. 1995, Yip \& Kurtz 1995). Furthermore, any underestimate of seaweed surface area would result in an overestimate of both the rate of uptake per unit surface area and the apparent permeability. The functional surface area of our seaweeds could be greater because of the presence of hyaline hairs (see below) and/or the ratio of plasma membrane surface area:tissue surface area. The value for the latter is 8.35 in Ulva rigida (MacFarlane \& Smith 1982); this would decrease our apparent permeability to $19 \mu \mathrm{m} \mathrm{s}^{-1}$.

For some seaweeds, the relationship between uptake rate and concentration is a combination of a hyperbolic component due to active uptake and a linear diffusive component (Harrison \& Druehl 1982). Examples from multiple-flask experiments include Fucus distichus (Thomas et al. 1985), F. spiralis (Topinka 1978), and Ulva lactuca (Pedersen 1994). These algae have SA:V ratios of 30,34 and $400 \mathrm{~cm}^{2}: 1 \mathrm{~cm}^{3}$ (Hein et al. 1995), respectively. We have calculated the rate of uptake at $10 \mu \mathrm{M}$ for the apparent diffusive component in these algae as $2.8,2.0$ and $6.8 \mu \mathrm{mol} \mathrm{g} \mathrm{DW} W^{-1}$ $\mathrm{h}^{-1}$, respectively. These values are close to the rates of uptake for seaweeds of comparable SA:V ratios from the Mokohinau Islands (Fig. 1). From Topinka (1978), we calculate a value of $23 \mathrm{nmol} \mathrm{cm} \mathrm{cm}^{-2} \mathrm{~h}^{-1}$ for the apparent diffusive component in $F$. spiralis at $15^{\circ} \mathrm{C}$, which is very close to the rate $0^{\text {: }}$ uptake (measured at $17.5^{\circ} \mathrm{C}$ ) for the 5 seaweed species from the Mokohinau Islands (Fig. 2). The apparent diffusive component in F. spiralis decreases with decreasing temperature (Topinka 1978). This observation could be accounted for by a decreased membrane permeability for $\mathrm{NH}_{3}$ with decreased temperature (Bindslev \& Wright 1976, Labotka et al. 1995).

Other southern hemisphere seaweeds also have low rates of ammonium uptake. Ecklonia radiata from western Australia has a SA:V ratio of $27 \mathrm{~cm}^{2} \cdot 1 \mathrm{~cm}^{3}$ and an uptake rate of $2.6 \mu \mathrm{mol} \mathrm{g} \mathrm{DW}^{-1} \mathrm{~h}^{-1}$ with $10 \mu \mathrm{M}$ ammonium, and the rate of uptake is a linear function of increasing ammonium concentration (Paling 1991). In addition, E. maxima from South Africa has an uptake rate of $2.1 \mu \mathrm{mol} g \mathrm{DW}^{-1} \mathrm{~h}^{-1}$ with $10 \mu \mathrm{M}$ ammonium (Probyn \& McQuaid 1985). Fucoid algae from Scotland also exhibit low rates of ammonium uptake compared with their North American counterparts (Brenchley et al. 1997). In both Xiphophora chondrophylla and Ulva sp. the rate of ammonium uptake was a linear function of ammonium concentration (Fig. 3). In contrast, most northern hemisphere seaweeds exhibit saturable or biphasic kinetics. However, there are a few exceptions, including Gracilaria tikvahiae (Friedlander \& Dawes 1985), low-intertidal Gracilaria pacifica (Thomas et al. 1987), and Laminaria groenlandica (Harrison et al. 1986). For the 2 Pacific 
seaweeds, we calculate that the rates of uptake at

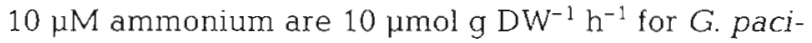
fica and 0.8 to $3.2 \mu \mathrm{mol} \mathrm{g} \mathrm{DW}^{-1} \mathrm{~h}^{-1}$ for L. groenlandica. Assuming that the SA:V ratio for $G$. tikvahiae (Hein et al. 1995) is similar to that for G. pacifica, the rate for $G$. pacifica is close to that for other North American seaweeds (Fig. 1). However, the rates for L. groenlandica are close to those we obtained for another member of the Laminariales, Lessonia variegata (Table 1), assuming a similar $\mathrm{SA}: \mathrm{V}$ ratio

One possible reason for the difference in rates of uptake between seaweeds with the same apparent SA:V ratios is the presence or absence of hyaline hairs (Whitton 1988). The method that we, and others, have used to measure the surface area of seaweeds is relatively coarse and would lead to an underestimate if hairs were present. For example, hairs increase the thallus surface area by $180 \%$ in Gracilaria pacifica and by $50 \%$ in Gelidium vagum (Oates \& Cole 1994). Though seaweeds with hairs have been shown to possess increased rates of nutrient uptake (DeBoer \& Whoriskey 1983, Hurd et al. 1993), it is unlikely that this alone would account for the discrepancy between uptake rates of plants from the Mokohinau Islands and the east coast of North America (Fig. 1). Rates of ammonium uptake by Ceramium rubrum are up to 2.7 times greater in plants with hairs (DeBoer \& Whoriskey 1983) and rates of phosphate uptake in Fucus spiralis are up to 3.5 times greater in plants with hairs than those without (Hurd et al. 1993). These increases are not sufficient to account for the discrepancy in uptake rates at low SA:V ratios (Fig. 1). Moreover, local $C$. rubrum possesses hairs (our observations), as does another New Zealand seaweed, Gelidium caulacantheum (Dromgoole \& Booth 1985).

Nitrogen-replete algae should exhibit low rates of ammonium uptake, with most or all of this uptake being due to passive diffusion of $\mathrm{NH}_{3}$ (Rees 1995). In contrast, nitrogen-deficient algae should possess high ammonium uptake rates due, in part, to the possession of an $\mathrm{NH}_{4}{ }^{+}$transport system (D'Elia \& DeBoer 1978 , Rosenberg et al. 1984, Fujita 1985, Pedersen 1994, Rees 1995, McGlathery et al. 1996). These characteristics would suggest that seaweeds from the Mokohinau Islands are nitrogen-replete, whereas those from the east coast of North America are relatively nitrogendeficient. However, concentrations of inorganic nitrogen (ammonium, nitrate and nitrite) during the austral summer at the Mokohinau Islands were low $(0.5 \mu \mathrm{M})$, suggesting that seaweeds collected during this period should have possessed higher rates of ammonium uptake. We found no pattern of increased rates of ammonium uptake for seaweeds collected during the austral summer (data not shown). An alternative explanation is that growth of seaweeds at the Mokohinau
Islands was limited by the availability of a nutrient other than nitrogen, e.g. phosphorus (Lapointe 1987. Lobban \& Harrison 1994) or iron (Matsunaga et al. 1994, Suzuki et al. 1995).

Acknowledgements. We are grateful to $\mathrm{M}$. Hein for providing data from Hein et al. (1995), to Brian Dobson for nutrient analyses, and to $C$. Hurd and the referees for their comments on drafts of the manuscript. This work was supported by a grant from the University of Auckland Research Committee to T.A.V.R.

\section{LITERATURE CITED}

Barr CE, Koh MS, Ryan TE (1974) $\mathrm{NH}_{3}$ efflux as a means of measuring $\mathrm{H}^{+}$extrusion in Nitella. In: Zimmerman $\mathrm{U}$, Dainty $J$ (eds) Membrane transport in plants. SpringerVerlag, New York, p 180-185

Bindslev N, Wright EM (1976) Effect of temperature on non electrolyte permeation across the toad urinary bladder. J Membr Biol 29:265-288

Brenchley JL, Raven JA, Johnston AM (1997) Resource acquisition in two intertidal fucoid seaweeds, Fucus serratus and Himanthalia elongata: seasonal variation and effects of reproductive development. Mar Biol 129:367-375

DeBoer JA, Whoriskey FG (1983) Production and role of hyaline hairs in Ceramium rubrum. Mar Biol 77:229-234

D'Elia CF, DeBoer JA. (1978) Nutritional studies of two red algae. II. Kinetics of ammonium and nitrate uptake. J Phycol 14:266-272

Dromgoole FI, Booth WE (1985) The structure and development of hairs on the thallus of Gelidum caulacantheum J. Ag. NZ J Mar Freshwat Res 19:43-48

Friedlander M, Dawes CJ (1985) In situ uptake kinetics of ammonium and phosphate and chemical composition of the red seaweed Gracilaria tikvahiae. J Phycol 21:448-453

Fujita RM (1985) The role of nitrogen status in regulating transient ammonium uptake and nitrogen storage by macroalgae. J Exp Mar Biol Ecol 92:283-301

Harrison PJ, Druehl LD (1982) Nutrient uptake and growth in the Laminariales and other macrophytes: a consideration of methods. In: Srivastava LM (ed) Synthetic and degradative processes in marine macrophytes. Walter de Gruyter \& Co, Berlin, p $99-120$

Harrison PJ, Druehl LD, Lloyd KE, Thompson PA (1986) Nitrogen uptake kinetics in three year-classes of Laminaria groenlandica (Laminariales: Phaeophyta). Mar Biol 93:29-35

Hein M, Pedersen MF, Sand-Jensen K (1995) Size-dependent nitrogen uptake in micro- and macroalgae. Mar Ecol Prog Ser 118:247-253

Hurd CL, Galvin RS, Norton TA, Dring MJ (1993) Production of hyaline hairs by intertidal species of Fucus (Fucales) and their role in phosphate uptake. J Phycol 29:160-165

Koroleff $F$ (1983) Determination of ammonia. In: Grasshoff K, Ehrhardt M, Kremling K (eds) Methods of seawater analysis. Verlag Chemie, Weinheim, p 150-157

Labotka RJ, Lundberg P, Kuchel PW (1995) Ammonia permeability of erythrocyte membrane studied by ${ }^{14} \mathrm{~N}$ and ${ }^{15} \mathrm{~N}$ saturation transfer NMR spectroscopy. Am J Physiol 268: C686-C699

Lapointe BE (1987) Phosphorus- and nitrogen-limited photosynthesis and growth of Gracilaria tikvahiae (Rhodophyceaej in the Floricla Keys: an experimental field study. Mar Biol 93:561-568 
Leigh EG, Paine RT, Quinn JF, Suchanek TH (1987) Wave energy and intertidal productivity. Proc Natl Acad Sci USA 84:1314-1318

Lobban CS. Harrison PJ (1994) Seaweed ecology and physiology. Cambridge University Press

MacFarlane JJ, Smith FA (1982) Uptake of methylamine by Ulva rigida: transport of cations and diffusion of free base. J Exp Bot 33:195-207

Mann KH, Chapman ARO, Gagne JA (1980) Productivity of seaweeds: the potential and the reality. In: Falkowski PG (ed) Primary productivity in the sea. Plenum Press, New York, p 363-380

Matsunaga K, Suzuki Y, Kuma K, Kudo I (1994) Diffusion of Fe(II) from an iron propagation cage and its effect on tissue iron and pigments of macroalgae on the cage. J Appl Phycol 6:397-403

McGlathery KJ, Pedersen MF, Borum J (1996) Changes in intracellular nitrogen pools and feedback controls on nitrogen uptake in Chaetomorpha linum (Chlorophyta). J Phycol 32:393-401

Oates BR, Cole KM (1994) Comparative studies on hair cells of two agarophyte algae, Gelidium vagum (Gelidiales, Rhodophyta) and Gracilaria pacifica (Gracilariales, Rhodophyta). Phycologia 33:420-433

Paling EI (1991) The relationship between nitrogen recycling and productivity in macroalgal stands and seagrass meadows. PhD thesis, University of Western Australia

Parsons TR, Maita Y, Lalli CM (1984) A manual of chemical and biological methods for seawater analysis. Pergamon Press, Oxford

Pedersen MF (1994) Transient ammonium uptake in the macroalga Ulva lactuca (Chlorophyta): nature, regulation, and the consequences for choice of measuring technique. J Phycol 30:980-986

Probyn TA, McQuaid CD (1985) In-situ measurements of nitrogenous nutrient uptake by kelp (Ecklonia maxima) and phytoplankton in a nitrate-rich upwelling environment. Mar Biol 88:149-1.54

Raven JA (1984) Energetics and transport in aquatic plants. Alan R Liss, New York

Rees TAV (1995) On ammonia futile cycling in a marine unicellular alga. Biochim Biophys Acta 1228:254-260

Rees TAV, Grant CM, Harmens HE, Taylor RB (1998) Rates of ammonium assimilation in marine algae: use of the protonophore carbonyl cyanide m-chlorophenylhydrazone to distinguish between uptake and assimilation. J Phycol 34:264-272

Editorial responsibility: Otto Kinne (Editor),

Oldendorf/Luhe, Germany
Ritchie RJ (1987) The permeability of ammonia, methylamine and ethylamine in the charophyte Chara corallina ( $C$. australis). J Exp Bot 38:67-76

Ritchie RJ, Gibson J (1987) Permeability of ammonia, methylamine and ethylamine in the cyanobacterium, Synechococcus R-2 (Anacystis nidulans) PCC 7942. J Membr Biol 95:131-142

Rosenberg G, Probyn TA, Mann KH (1984) Nutrient uptake and growth kinetics in brown seaweeds: response to continuous and single additions of ammonium. J Exp Mar Biol Ecol 80:125-146

Rosenberg G, Ramus J (1984) Uptake of inorganic nitrogen and seaweed surface area:volume ratio. Aquat Bot 19:65-72

Sharp JH (1983) The distributions of inorganic nitrogen and dissolved and particulate organic nitrogen in the sea. In: Carpenter EJ, Capone DG (eds) Nitrogen in the marine environment. Academic Press, New York, p 1-35

Sokal RR, Rohlf FJ (1995) Biometry, 3rd edn. WH Freeman. New York

Suzuki Y, Kuma K, Kudo I, Matsunaga K (1995) Iron requirement of the brown macroalgae Laminaria japonica, Undaria pinnatifida (Phaeophyta) and the crustose coralline alga Lithophyllum yessoense (Rhodophyta), and their competition in the northern Japan Sea. Phycologia 34:201-205

Taylor RB, Rees TAV (in press) Excretory products of mobile epifauna as a nitrogen source for seaweeds. Limnol Oceanogr (in press)

Thomas TE, Harrison PJ, Taylor EB (1985) Nitrogen uptake and growth of the germlings and mature thalli of Fucus distichus. Mar Biol 84:267-274

Thomas TE, Harrison PJ, Turpin DH (1987) Adaptations of Giacilaria pacifica (Rhodophyta) to nitrogen procurement at different intertidal locations. Mar Biol 93:569-580

Topinka JA (1978) Nitrogen uptake by Fucus spiralis (Phaeophyceae). J Phycol 14:241-247

Wallentinus I (1984) Comparisons of nutrient uptake rates for Baltic macroalgae with different thallus morphologies. Mar Biol 80:215-225

Whitton BA (1988) Hairs in eukaryotic algae. In: Round FE (ed) Algae and the aquatic environment. Biopress Ltd, Bristol, p 446-460

Yip KP, Kurtz I (1995) $\mathrm{NH}_{3}$ permeability of principal cells and intercalated cells measured by confocal fluorescence imaging. Am J Physiol 269:F545-F550

Zar JH (1984) Biostatistical analysis, 2nd edn. Prentice-Hall, Englewood Cliffs, NJ

Submitted: August 26, 1997; Accepted: May 11, 1998

Proofs received from author(s): June 26, 1998 